\title{
An investigation of pre-service English teachers' level of technopedagogical content knowledge*
}

\author{
Cihat Atar ${ }^{a}+\dagger$, Selami Aydın ${ }^{\text {(D) }}$, Hakkı Bağc1 ${ }^{c}$ \\ ${ }^{a}$ Sakarya University, Serdivan, Sakarya, Turkey \\ ${ }^{b}$ Istanbul Medeniyet University, Kartal, Istanbul, Turkey \\ ${ }^{c}$ Sakarya University, Serdivan, Sakarya, Turkey \\ APA Citation: \\ Atar, C., Aydın, S., \& Bağc1, H. (2019). An investigation of pre-service English teachers' level of technopedagogical content knowledge. \\ Journal of Language and Linguistic Studies, 15(3), 794-805. \\ Submission Date:19/11/2018 \\ Acceptance Date:09/07/2019
}

\begin{abstract}
The purpose of this study is to identify pre-service English teachers' technopedagogic content knowledge competence levels. The Technological Pedagogical Content Knowledge Model (TPACK) is unique in comparison to other technology-based models in that it incorporates content knowledge as well in addition to technological competences. The participants are 182 pre-service English teachers that study in Istanbul and Sakarya, Turkey. The data was collected via Technological Pedagogical Content Knowledge Scale (TPACK-Deep) that was developed by Kabakçı Yurdakul, Odabaşı, Kılıçer, Çoklar, Birinci and Kurt (2012). The data was analyzed through SPSS and the variables grade, gender, daily amount of time spent on the internet and social media were considered in addition to identifying participants' competence levels. The findings demonstrated that the participants had a high level of TPACK model in general and also in the three dimensions except for merely the Ethics dimension in which they had a medium level of competence. Out of the variables, none of them was observed to have a significant effect in the TPACK model in a general, but gender and daily amount of time spent on the internet were observed to have a significant effect on the Design dimension. The analysis offers insights into pre-service teachers' competence into technology use, content knowledge, pedagogical knowledge and their integration. The findings are expected to contribute to pre-service teacher training and the successful integration of technology into content knowledge for pedagogic purposes.
\end{abstract}

(C) 2019 JLLS and the Authors - Published by JLLS.

Keywords: Technopedagogical content knowledge; TPACK; pre-service English teachers; technology; content knowledge

\section{Introduction}

Here Today we live in the technology age and every aspect of this era changes in a fast way. This fast change forces individuals and societies to react promptly to catch up with the latest developments. This situation is also indispensable for educational contexts and the perspectives of the stakeholders

\footnotetext{
* This paper is based on the oral presentation 'Atar, C., Aydın, S. \& Bağcı, H. (2018) Pre-service teachers' perceptions of research skills' presented at II. International Conference Research in Applied Linguistics in 11-12 October 2018, in Malatya-TURKEY.

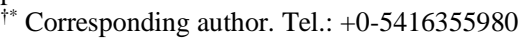

E-mail address: cihatatar@sakarya.edu.tr
} 
should be in line with the novelties. Technology and especially the internet have a fundamental role in human civilization. Consequently, pre-service teachers, as prospective teachers, should be equipped with the necessary and up-to-date skills. In technology use for pedagogy, attitudes have a significant role as positive attitudes suggest that pre-service teachers will not only be much more willing to utilize technology for pedagogical goals but also, they will be more likely to be open to improve themselves regarding the utilizations of technology for educational purposes (Bağc1 \& Atar, 2018). Moreover, technological knowledge together with pedagogical knowledge is important in that teachers who claim to use technology tend to use it for communication purposes, for preparation to the lessons (Russell, Bebell, O'Dwyer, \& O'Connor, 2003) or for projecting powerpoint slides and the course books on the blackboard. However, teachers who can use technology blended with appropriate pedagogical knowledge can create an environment in which students can control their learning and learn at their own pace (Bağc1 \& Atar, 2018). In this sense, technology use is goal oriented and it is not used for the sake of using it.

Accordingly, it may be argued that teachers ought to be able to integrate technology into lessons successfully. This also depends on the pedagogical goals the use of technology serves. They should use their pedagogical knowledge to decide how technology use can be fruitful for students' learning. However, as will be argued in the literature review section below, there are not enough studies in this field and as it is a significant issue, further studies are needed. This study aims at contributing to this gap and in response to this justification. The model of Technological Pedagogical Content Knowledge (TPACK) emerged quite recently and it consists of the integration of pedagogic content knowledge and technology knowledge (Koehler \& Mischra, 2008; Tuncer \& Bahadır, 2016). TPACK has a threedimensional structure which consists of Technology, Content and Pedagogy. TPACK involves the integration of a certain content into a practice that is based on educational technology. Hence, it has a relationship with the dimensions of educational technology programs. It also correlates with educational goals. In technopedagogical education, the vital issue is to blend pedagogical and content knowledge and use technology to support them in a meaningful way. The constructive alignment of these three aspects is the critical point which is expected to be more successful compared to traditional approaches (Bruce \& Levin, 1997; Kabakçı Yurdakul, 2011). As for TPACK competence, it is the utilization of technopedagogic education, pedagogy and content knowledge in together in addition to the use and integration of appropriate technologies in classrooms. Namely, forming a link between the three areas (pedagogy, technology and content knowledge) are underlined (Bruce \& Levin, 1997). Considering this, the aim of this paper is to designate pre-service English teachers' technopedagogical knowledge level and whether this level varies depending on gender, year and daily time spent on the internet.

\subsection{Literature review}

When the relevant literature was checked, several studies that are related to technopedagogical competence were found (Şimşek, Demir, Bağçeci, \& Kinay, 2013; Murat \& Erten, 2016; İşigüzel, 2014; Kabakçı Yurdakul, 2011; Tuncer \& Bahadır, 2016; Argon, İsmetoğlu \& Çelik Yılmaz, 2015). In the following paragraphs, first, the studies that analyzed the TPACK level will be presented. Then, the studies that focus on the effects of different variables on the level of TPACK will be discussed. Finally, some experimental studies which analyzed the effect of explicit teaching of TPACK will be considered.

The first group of studies is on the level of TPACK. For instance, in her study, Kabakçı Yurdakul (2011) found that pre-service teachers usually had high levels in TPACK. In the study undertaken on pre-service German teachers, İşigüzel (2014) found that the participants' technological pedagogical levels are at a high level. In the same vein, Şimşek et al. (2013) found that instructors' TPACK is at a high level. Argon, İsmetoğlu \& Çelik Yılmaz (2015) did a study on teachers who taught a specific subject matter. They found that teachers' TPACK was at a medium level. Murat \& Erten (2016) studied 
self-efficacy levels of pre-service science teachers. Their results suggested that pre-service teachers usually viewed themselves as competent in TPACK components. One study that studied pre-service English teachers is Öz (2015) who studied the participants' TPACK competence. This study used a TPACK scale which focused on all the aspects of TPACK and found that pre-service teachers had a high level of TPACK competence.

In their study in which they checked teachers' technopedagogic competence levels, Archambault \& Crippen (2009) found that the teachers who do their teaching in online environments had a high level in pedagogy, content and pedagogical content while they had less confidence in themselves when technological knowledge was added to the knowledge types. Aygün, Uzun \& Atasoy (2016) studied preservice teacher's TPACK competence. Their study showed that pre-service teachers used technology as an exploratory tool in initial teaching and they prepared technology supported activities for dealing with conceptual misunderstandings; however, they had difficulty in using technology in the process of evaluation.

The next group of studies is the studies which checked the effects of different variables on the levels of TPACK. In their study, Murat \& Erten (2016) checked whether gender makes a difference in TPACK levels and they concluded that it has no significant effect. Similarly, Şimşek et al. (2013) found that gender of instructors did not their TPACK levels in a significant way. Some studies also showed that gender does not lead to a significant change in the level of TPACK (Ünal Bozcan, 2010; İşigüzel, 2014; Kaya, Özdemir, Emre, \& Kaya, 2011; Kula, 2015). However, in the literature, there are a few studies which found that TPACK levels vary depending on gender (Argon et al., 2015; Tuncer \& Bahadır, 2016; Kazu \& Erten, 2014).

Finally, there are also some studies which designed interventions to increase TPACK levels (Tondeur, Roblin, van Braak, Fisser, \& Voogt, 2012; Kurt, Mishra, \& Koçoğlu, 2013). For instance, Kurt et al. (2013, as cited in Öz, 2015) implemented a 12-week explicit TPACK teaching to pre-service English teachers to see the results of the intervention. The outcomes demonstrated that there was a significant increase in TPACK levels. Ersoy, Kabakçı Yurdakul \& Ceylan (2016) undertook an experimental study and their results showed that when the use of information and communication technologies increase, they as a variable positively correlated with the participants' TPACK competence. Via the courses they organized, Jang \& Chen (2010) found that the use and experience of technology based on technopedagogic content knowledge is significant in developing technopedagogic content knowledge competence.

\subsection{Research questions}

Regarding the justification and potential advantages (see section 2.2) of the TPACK model (Yurdakul et al., 2012), this study aims to study two research questions:

1) What is the level of pre-service English teachers' TPACK?

2) To what extent does this level vary depending on gender, year, daily time spent on the internet and daily time spent on social networks?

\section{Method}

This study utilized a survey research model. Survey models aim at describing a phenomena as they exist in real life. The focus and participants are studied as they occur in their real-life contexts (Karasar, 2005). This study also utilized a correlational survey model considering the second research question of this study. 


\subsection{Sample}

182 pre-service English teachers studying in the Faculty of Education at two state universities in Istanbul and Sakarya in 2018-2019 comprise the sample. Table 1 presents some of the information about the participants.

Table 1. Information about the participants

\begin{tabular}{llcc}
\hline \multirow{2}{*}{ Variables } & & $\mathrm{f}$ & $\%$ \\
\hline \multirow{2}{*}{ Gender } & & & \\
& Male & 62 & 34.1 \\
& Female & 120 & 65.9 \\
\hline \multirow{2}{*}{ Class } & 1st Year & 82 & 45.1 \\
& 2nd Year & 52 & 28.6 \\
& 3rd Year & 33 & 18.1 \\
Daily Internet Use & 4th Year & 15 & 8.2 \\
& $0-3$ hours & 60 & 33.0 \\
& $3-5$ hours & 59 & 32.4 \\
\multirow{2}{*}{ Daily Social Network Use } & More than 5 hours & 63 & 34.6 \\
& $0-1$ hour & 48 & 26.4 \\
& $1-3$ hours & 76 & 41.8 \\
\hline Total & $3-5$ hours & 27 & 14.8 \\
\hline
\end{tabular}

As seen in Table 1, the participants of the study are 182 pre-service English teachers. 62 of the participants $(34.1 \%)$ are males while 120 of them (65.9\%) are females. 82 of the participants $(45.1 \%)$ are $1^{\text {st }}$ year students, 52 of them $(28.6 \%)$ are $2^{\text {nd }}$ year students, 33 of them $(18.1 \%)$ are $3^{\text {rd }}$ year students and 15 of them $(8,2 \%)$ are $4^{\text {th }}$ year students.

\subsection{Data collection tool}

The TPACK scale (Yurdakul et al., 2012) consisting of 33 items and 4 factors (design (10), exertion (12), ethics (6) and proficiency (5)) was used to collect the data. To illustrate some of the items, "Being able to behave in an ethical way regarding the access to technology in education settings" is an item under ethics while "Being able to plan the teaching-learning process according to technological opportunities" is under design.

The Cronbach's Alpha internal reliability coefficient is calculated as .95 . The factors that form the scale have values between .85 and .92 . The Cronbach's Alpha internal reliability coefficient for the whole scale is calculated as .949 . There are several studies and scales in the literature regarding TPACK but, the scale in this study is specifically designed to focus specifically on technological and content dimensions. Accordingly, it is the appropriate scale regarding our sample and the goals of the current article.

\subsection{Data analysis}

The highest point for the items in the scale is 5 and the lowest point is 1 . In order to assess pre-service English teachers' TPACK level, evaluation criteria consisting of 3 intervals were created based on the average values (Table 2). 
Table 2. TPACK Evaluation Intervals

\begin{tabular}{lc}
\hline Evaluation Criteria & Evaluation Interval \\
\hline Low & $1.00-2.33$ \\
Medium & $2.34-3.67$ \\
High & $3.68-5.00$ \\
\hline
\end{tabular}

The data collected from the pre-service teachers were analyzed by SPSS 16.0 (Statistical Package for the Social Sciences) and the significance level was determined as .05. While doing an analysis on the variables that had two different sub-groups, independent samples t-tests were utilized while variance analysis was used in variables that had more than two sub-groups. In the literature, independent samples $\mathrm{t}$-tests are utilized to test the significance of the means between independent samples. The measurement for the dependent variable should be the least equally spaced and the independent variable should have two categories and be discrete (Büyüköztürk, 2010). As for variance analysis, it is used to test if the difference between the means of two or more independent samples are different than null in a significant way (Büyüköztürk, 2010).

\section{Results}

The findings were presented with regard to the 2 research questions below.

\subsection{What is the level of pre-service English teachers' TPACK?}

The data were analyzed with regard to the four aspects: design, exertion, ethics and proficiency to answer this research question. The findings were presented below.

Table 3. Pre-service English teachers' level of TPACK

\begin{tabular}{lll}
\hline Sub-Dimensions & $\overline{\mathrm{X}}$ & SD \\
\hline Design & 3.98 & .55 \\
Exertion & 3.88 & .54 \\
Ethics & 3.66 & .67 \\
Proficiency & 4.02 & .65 \\
\hline General & 3.89 & .53 \\
\hline
\end{tabular}

The findings show that pre-service English teachers in this study have a high level of TPACK with an average of 3.89. When the sub-dimensions were analyzed, it was observed that the averages for Design are 3.98, it is 3.88 for Exertion, it is 3.66 for Ethics and it is 4.02 for Proficiency. These results demonstrated that they have high levels of TPACK in Design, Exertion and Proficiency while they have a medium level of TPACK for Ethics.

3.2. To what extent does this level vary depending on gender, year, daily time spent on the internet and daily time spent on social networks?

Firstly, the study checked whether gender had any significant role in the participants' TPACK levels. An Independent Samples T-test was undertaken to designate this effect. The findings were presented in Table 3 below. 
Table 4. Pre-service Teachers' Technopedagogical Competence with regard to Gender

\begin{tabular}{|c|c|c|c|c|c|c|c|}
\hline Sub-Dimensions & Groups & $\mathbf{n}$ & $\bar{X}$ & Sd & df & $\mathbf{t}$ & $\mathbf{p}$ \\
\hline \multirow{2}{*}{ Design } & Male & 62 & 4.13 & .51 & \multirow{2}{*}{180} & \multirow{2}{*}{2.689} & \multirow{2}{*}{.008} \\
\hline & Female & 120 & 3.91 & .56 & & & \\
\hline \multirow{2}{*}{ Exertion } & Male & 62 & 3.96 & .48 & \multirow{2}{*}{180} & \multirow{2}{*}{1.313} & \multirow{2}{*}{.191} \\
\hline & Female & 120 & 3.84 & .57 & & & \\
\hline \multirow{2}{*}{ Ethics } & Male & 62 & 3.76 & .59 & \multirow{2}{*}{180} & \multirow{2}{*}{1.470} & \multirow{2}{*}{.143} \\
\hline & Female & 120 & 3.61 & .71 & & & \\
\hline \multirow{2}{*}{ Proficiency } & Male & 62 & 4.00 & .67 & \multirow{2}{*}{180} & \multirow{2}{*}{-.229} & \multirow{2}{*}{.819} \\
\hline & Female & 120 & 4.02 & .65 & & & \\
\hline \multirow{2}{*}{ GENERAL } & Male & 62 & 3.98 & .48 & \multirow{2}{*}{180} & \multirow{2}{*}{1.631} & \multirow{2}{*}{.105} \\
\hline & Female & 120 & 3.85 & .55 & & & \\
\hline
\end{tabular}

The results demonstrated that in general, gender had no significant effects [t(180)=1.631, $\mathrm{p}>.05]$. This is also true for 3 of the sub-dimensions: Exertion, Ethics and Proficiency. However, the results indicated that gender had a role in the Design sub-dimension [t(180)=1.631, p>.05]. In addition, while the difference in averages was around .10 for the three aspects, it was .22 for design. This showed that gender gave way to a significant difference and males were observed to have a higher score in Design.

In order to analyze the second variable which may have an effect on pre-service teachers' TPACK, the Kruskall Wallis test was undertaken to analyze the effects of the year in which participants study. The results were presented below.

Table 5. Pre-service Teachers' Technopedagogical Competence with regard to Year

\begin{tabular}{|c|c|c|c|c|c|c|c|}
\hline $\begin{array}{c}\text { Sub- } \\
\text { Dimensions }\end{array}$ & Groups & $\mathrm{n}$ & Median & $\mathrm{Sd}$ & $X^{2}$ & $\mathrm{p}$ & Significance \\
\hline \multirow{4}{*}{ Design } & 1st Year & 82 & 84.59 & \multirow{4}{*}{3} & \multirow{4}{*}{3.476} & \multirow{4}{*}{.324} & \multirow{4}{*}{ None } \\
\hline & 2nd Year & 52 & 96.73 & & & & \\
\hline & 3rd Year & 33 & 102.47 & & & & \\
\hline & 4th Year & 15 & 87.00 & & & & \\
\hline \multirow{4}{*}{ Exertion } & 1st Year & 82 & 86.84 & \multirow{4}{*}{3} & \multirow{4}{*}{3.704} & \multirow{4}{*}{.295} & \multirow{4}{*}{ None } \\
\hline & 2nd Year & 52 & 96.99 & & & & \\
\hline & 3rd Year & 33 & 101.48 & & & & \\
\hline & 4th Year & 15 & 76.00 & & & & \\
\hline \multirow{4}{*}{ Ethics } & 1st Year & 82 & 87.38 & \multirow{4}{*}{3} & \multirow{4}{*}{5.763} & \multirow{4}{*}{.124} & \multirow{4}{*}{ None } \\
\hline & 2nd Year & 52 & 99.44 & & & & \\
\hline & 3rd Year & 33 & 100.18 & & & & \\
\hline & 4th Year & 15 & 67.37 & & & & \\
\hline \multirow{4}{*}{ Proficiency } & 1st Year & 82 & 87.88 & \multirow{4}{*}{3} & \multirow{4}{*}{2.871} & \multirow{4}{*}{.412} & \multirow{4}{*}{ None } \\
\hline & 2nd Year & 52 & 98.87 & & & & \\
\hline & 3rd Year & 33 & 95.73 & & & & \\
\hline & 4th Year & 15 & 76.43 & & & & \\
\hline \multirow{4}{*}{ GENERAL } & 1st Year & 82 & 86.09 & \multirow{4}{*}{3} & \multirow{4}{*}{4.225} & \multirow{4}{*}{.238} & \multirow{4}{*}{ None } \\
\hline & 2nd Year & 52 & 97.98 & & & & \\
\hline & 3rd Year & 33 & 101.80 & & & & \\
\hline & 4th Year & 15 & 75.93 & & & & \\
\hline
\end{tabular}


According to the analysis, no significant difference was observed in pre-service teachers' TPACK level considering the class they were in $[\mathrm{X} 2(3)=4.225$, p>.05]. This was also valid for all the subdimensions. Consequently, it may be argued that this variable did not cause any significant differences.

The third variable was daily internet use. A variance analysis was undertaken to see its effect on TPACK levels. The findings were presented in Table 5 below.

Table 6. Pre-service Teachers’ Technopedagogical Competence with regard to Daily Internet Use

\begin{tabular}{|c|c|c|c|c|c|c|c|}
\hline Sub-Dimensions & $\begin{array}{l}\text { Source of the } \\
\text { Variation }\end{array}$ & K.T & $\mathrm{Sd}$ & K.O & $\mathrm{F}$ & $\mathrm{p}$ & Significance \\
\hline \multirow{3}{*}{ Design } & Intergroup & 2.912 & 2 & 1.456 & \multirow{3}{*}{4.960} & \multirow{3}{*}{.008} & \multirow{3}{*}{$3-1 *$} \\
\hline & Intragroup & 52.545 & 179 & .294 & & & \\
\hline & Total & 55.457 & 181 & & & & \\
\hline \multirow{3}{*}{ Exertion } & Intergroup & .901 & 2 & .451 & \multirow{3}{*}{1.540} & \multirow{3}{*}{.217} & \multirow{3}{*}{ None } \\
\hline & Intragroup & 52.377 & 179 & .293 & & & \\
\hline & Total & 53.278 & 181 & & & & \\
\hline \multirow{3}{*}{ Ethics } & Intergroup & .936 & 2 & .468 & \multirow{3}{*}{1.039} & \multirow{3}{*}{.356} & \multirow{3}{*}{ None } \\
\hline & Intragroup & 80.610 & 179 & .450 & & & \\
\hline & Total & 81.546 & 181 & & & & \\
\hline \multirow{3}{*}{ Proficiency } & Intergroup & 1.022 & 2 & .511 & \multirow{3}{*}{1.199} & \multirow{3}{*}{.304} & \multirow{3}{*}{ None } \\
\hline & Intragroup & 76.314 & 179 & .426 & & & \\
\hline & Total & 77.336 & 181 & & & & \\
\hline \multirow{3}{*}{ GENERAL } & Intergroup & 1.372 & 2 & .686 & \multirow{3}{*}{2.498} & \multirow{3}{*}{.085} & \multirow{3}{*}{ None } \\
\hline & Intragroup & 49.171 & 179 & .275 & & & \\
\hline & Total & 50.543 & 181 & & & & \\
\hline
\end{tabular}

*(1: 0-3 hours, 2: 3-5 hours, 3: more than 5 hours)

The analysis demonstrated that the amount of daily internet use does not affect pre-service teachers' TPACK level $[\mathrm{F}(2-181)=2.498, \mathrm{p}>.05]$ in a significant way. However, when the sub-dimensions were individually checked, Design was found to be affected by this variable $[F(2-181)=4.960, p<.05]$. In order to find out which groups had this significant difference with regard to the amount of daily time spent on the internet, the results of the Scheffe test were checked. The results demonstrated that those who spent 5 or more hours on the internet had higher levels of TPACK compared to those who spent 0-3 hours. Except for Design, the other sub-dimensions were observed to have no significant effect on the participants' TPACK level.

The final variable was the amount of daily time spent on social networks. In order to see the effect of this variable, a variance analysis was undertaken. The results were presented in Table 6 below.

Table 7. Pre-service Teachers' Technopedagogical Competence with regard to Daily Social Network Use

\begin{tabular}{llllllll}
\hline \multirow{2}{*}{ Sub-Dimensions } & $\begin{array}{l}\text { Source of the } \\
\text { Variation }\end{array}$ & K.T & S & K.O & F & p & Significance \\
\hline \multirow{3}{*}{ Design } & Intergroup & 1.086 & 3 & .362 \\
& Intragroup & 54.371 & 178 & .305 & 1.185 & .317 & None \\
\cline { 2 - 8 } & Total & 55.457 & 181 & & & \\
\hline
\end{tabular}




\begin{tabular}{|c|c|c|c|c|c|c|c|}
\hline \multirow{3}{*}{ Exertion } & Intergroup & 1.012 & 3 & .337 & \multirow{3}{*}{1.148} & \multirow{3}{*}{.331} & \multirow{3}{*}{ None } \\
\hline & Intragroup & 52.267 & 178 & .294 & & & \\
\hline & Total & 53.278 & 181 & & & & \\
\hline \multirow{3}{*}{ Ethics } & Intergroup & 1.523 & 3 & .508 & \multirow{3}{*}{1.129} & \multirow{3}{*}{.339} & \multirow{3}{*}{ None } \\
\hline & Intragroup & 80.023 & 178 & .450 & & & \\
\hline & Total & 81.546 & 181 & & & & \\
\hline \multirow{3}{*}{ Proficiency } & Intergroup & .497 & 3 & .166 & \multirow{3}{*}{.384} & \multirow{3}{*}{.765} & \multirow{3}{*}{ None } \\
\hline & Intragroup & 76.840 & 178 & .432 & & & \\
\hline & Total & 77.336 & 181 & & & & \\
\hline \multirow{3}{*}{ GENERAL } & Intergroup & .893 & 3 & .298 & \multirow{3}{*}{1.068} & \multirow{3}{*}{.364} & \multirow{3}{*}{ None } \\
\hline & Intragroup & 49.650 & 178 & .279 & & & \\
\hline & Total & 50.543 & 181 & & & & \\
\hline
\end{tabular}

The analysis indicated that there was no significant difference among the participants with regard to the daily amount of time spent on social networks $\mathrm{F}(2-181)=1.068, \mathrm{p}>.05]$. Furthermore, the results demonstrated that there was no significant difference for the sub-dimensions either.

\section{Discussion}

\subsection{What is the level of the participants' TPACK?}

The analysis of the findings suggested that the participants in this study had a high level of TPACK. This in line with the literature which usually indicated that pre-service teachers had a high level of TPACK (Kabakçı Yurdakul, 2011; İşigüzel, 2014; Öz, 2015; Şimşek et al., 2013) while there are few others who suggested that the participants had a medium level of TPACK (Argon et al., 2015). The difference in Argon et al. (2013) may stem from the difference in the participants. While this study studied pre-service teachers, Argon et al.'s (2013) sample consisted of teachers and as they mentioned in their study, two-thirds of their participants had a teaching experience of 6 or more years, which means that they are usually over 30 years old. In this sense, it may be argued that as these participants are relatively older compared to our sample, who are usually around 18-20, there may be a generation gap (i.e. Digital natives). Due to the sharp increase in the access to the technology, it could be suggested that the sample in this study has had more contact with using technology starting from a very young age, which in turn may have resulted in their being more competent in TPACK.

Also, the fact that the participants have a high level of TPACK competence is a valuable observation in that these students are usually 1 st and $2^{\text {nd }}$ year students. This may mean that they already have some of the essential features for using technology for pedagogical and appropriate contents. Moreover, their high level suggests that they will be more likely to have a positive attitude towards integrating technology into their teaching, which is expected to improve their teaching in the future (Bağc1 \& Atar, 2018).

The results also demonstrated that there was no significant difference for three of the sub-dimensions and the participants had a high level of competence in Design, Exertion and Proficiency. However, participants' level in the Ethics sub-dimension was found to be medium ( $\overline{\mathrm{X}}: 3.66)$. These results demonstrated that the participants had a high level of TPACK in Design, Exertion and Proficiency while they had a medium level of TPACK for Ethics. In general, this finding is also in line with the literature (Yurdakul Kabakç1, 2011; Murat \& Erten, 2016). Yet, these studies reported that pre-service teachers had a high level in Ethics as well. Why the participants had a medium level in Ethics in comparison to the other three sub-dimensions, may be a result of the year in which they study. In Kabakçı Yurdakul's 
study (2011), the participants are final year pre-service teachers and the participants of Murat \& Erten (2016) are $3^{\text {rd }}$ and $4^{\text {th }}$ year pre-service teachers. Consequently, the year in which the participants study may be argued to have an effect. The students in the 3rd and 4th grades have probably had more exposure to academic issues such as reading and writing articles, and they are probably more aware of ethical issues such as plagiarism in comparison to $1^{\text {st }}$ and $2^{\text {nd }}$ year students who usually attend introduction courses.

Finally, some experimental studies in the literature worth discussing in relation to this study. Ersoy et al. (2016) demonstrated that the increase in the use of information and communication technologies as a variable positively correlated with the participants' TPACK competence. Similarly, via the courses they organized, Jang \& Chen (2010) found that the use and experience of technology based on technopedagogic content knowledge is significant in developing technopedagogic content knowledge competence. This study showed that the participant pre-service teachers have high level of TPACK competence. Accordingly, it can be suggested pre-service teachers have a positive attitude towards TPACK and they are ready to incorporate technology, content knowledge and pedagogic knowledge. Consequently, it can be deduced that pre-service teachers' TPACK competence should be increased via interventions, project, workshops and so on.

\subsection{To what extent does pre-service English teachers' TPACK level vary depending on gender, year and daily time spent on the internet?}

The analysis regarding the effect of gender demonstrated that there is not a significant difference between the participants with regard to gender in general. However, a significant difference was observed only in one of the dimensions which is Design. The analysis showed that males were observed to have a higher score in this dimension. In the literature, there is not a consensus regarding the role of gender. There are several studies which demonstrated that gender had no significant effect on the level of TPACK (Ünal Bozcan, 2010; İşigüzel, 2014; Kaya et al., 2011; Şimşek et al., 2013; Kula, 2015). However, a few studies which found that TPACK levels vary depending on gender also exist in the literature (Argon et al., 2015; Tuncer \& Bahadır, 2016; Kazu \& Erten, 2014). Considering this situation, it may be argued that an in-depth study should be undertaken on gender to clarify the relationship between gender and TPACK levels, and check the possible factors that lead to different results.

As stated by Tondeur et al. (2012), previous research has shown that providing pre-service teachers with the chance to experience and learn how to use technology can improve teaching within specific content areas. As discussed above, most of the studies in the literature have shown that pre-service teachers have a high level of TPACK and they have a positive attitude towards the use of technology for pedagogical purposes (Bağcı \& Atar, 2018). Considering their readiness, interventions which allow pre-service teachers to experience and also learn how technology, content knowledge and pedagogical concerns can be aligned together will probably be more beneficial. Regarding its benefits, in the Turkish context, TPACK modules can be integrated into the English Language Teacher education curriculum via appropriate courses such as Instructional Technologies. However, the focus should be the integration of the three dimensions (Technology, Content and Pedagogy) rather than simply focusing on technological skills. Consequently, it can be argued that the goal should be moving from technology knowledge to utilizing technology to teach content via appropriate pedagogical approaches. In this way, firstly, pre-service teachers understand the educational reasons for integrating technology into lessons and technology is not used for the sake of using it. Also, by doing it themselves, pre-service teachers can experience its benefits and contribution to the teaching of content. 


\section{Conclusion}

This article has aimed to find out pre-service English teachers TPACK levels and whether variables had any effect upon this. To find out the participants' TPACK level, a scale that was developed by Yurdakul et al. (2012) to specifically address technological and content knowledge was utilized. The data were analyzed via SPSS 16.0 using independent samples t-tests and variance analysis. The results demonstrated that pre-service English teachers' TPACK level was high, which is in line with most of the literature. The only dimension that was not high was Ethics. As for the effects of variables, 3 of the variables were observed to have no significant effect while gender and daily time spent on the internet were observed to have an effect on merely the Design sub-dimension.

Overall, this study portrayed pre-service teachers' TPACK levels and the effects of some variables. Accordingly, some suggestions were made. For the future studies, the integration of TPACK into English Language Teaching curriculum is a promising area which will hopefully shed new light on how to integrate knowledge of technology, content and pedagogy to educate prospective English language teachers in accordance with the $21^{\text {st }}$ century skills. As demonstrated in Ersoy et al. (2016), the increase in the use of information and communication technologies as a variable positively correlated with the participants' TPACK competence. In the same vein, via the courses they organized, Jang \& Chen (2010) found that the use and experience of technology based on technopedagogic content knowledge is significant in developing technopedagogic content knowledge competence. Accordingly, it can be suggested that it is essential to have pre-service teachers be exposed to relevant pedagogic technologies. As shown by the mentioned studies, this has a significant effect on their technopedagogic competences.

As for the limitations, this study was based on a scale in which the participants assessed the items in accordance with their views and believes. In the future, rather than asking about believes/views, what they actually do may be checked in order to understand what they do in comparison to what they believe or think.

\section{References}

Argon, T., İsmetoğlu, M. \& Çelik Yılmaz, D. (2015). Branş öğretmenlerinin teknopedagojik eğitim yeterlilikleri ile bireysel yenilikçilik düzeylerine ilişkin görüşleri. Ĕgitim ve Öğretim Araştırmaları Dergisi, 4(2), 319-333.

Archambault, L. \& Crippen, K. (2009). Examining TPACK among K-12 online distance educators in the United States. Contemporary Issues in Technology and Teacher Education, 9(1), 71-88.

Aygün, B., Uzun, N. \& Atasoy, E. (2016). Öğretmen adaylarının teknopedagojik eğitim yeterliklerinin incelenmesi. Turkish Journal of Computer and Mathematics Education, 7(2), 393-416.

Bağc1, H. \& Atar, C. (2018) Pre-service English teachers' acceptance and use of social networks for learning and teaching purposes. Kuramsal Eğitimbilim Dergisi, UBEK-2018, 189-203.

Bruce, B. \& Levin, J. (1997). Educational technology: Media for inquiry, communication, construction and expression. Journal of Educational Computing Research, 17(1), 79-102.

Büyüköztürk, Ş. (2010). Sosyal Bilimler için Veri Analizi El Kitabı. Ankara: Pegem Akademi Yayınları.

Ersoy, M., Kabakçı Yurdakul, I. \& Ceylan, B. (2016). Öğretmen adaylarının BİT becerileri 1şığında teknopedagojik içerik bilgisine ilişkin yeterliklerinin incelenmesi: Deneysel bir araştırma. Ĕgitim ve Bilim, 41(186), 119-135. 
Jang, S. J. \& Chen, K. C. (2010). From PCK to TPACK: Developing a transformative model for preservice science teachers. Journal of Science Education and Technology, 19(6), 553-564.

İşigüzel, B. (2014). Almanca öğretmen adaylarının teknopedagojik eğitime yönelik yeterlik düzeylerinin incelenmesi. Uluslararası Sosyal Araştırmalar Dergisi, 7(34), 768-778.

Kabakçı Yurdakul, I. (2011). Öğretmen adaylarının teknopedagojik eğitim yeterliklerinin bilgi ve iletişim teknolojilerinin kullanımları açısından incelenmesi. Hacettepe Üniversitesi Eğitim Fakültesi Dergisi, 40, 397-408.

Kabakci Yurdakul, I., Odabasi, H. F., Kilicer, K., Coklar, A. N., Birinci, G. \& Kurt, A. A. (2012). The development, validity and reliability of TPACK-deep: A technological pedagogical content knowledge scale. Computers \& Education, 58(3), 964-977.

Karasar, N. (2005). Bilimsel araştırma yöntemi. Ankara: Nobel Yayın Dağıtım.

Kaya, Z., Özdemir, T. Y., Emre, İ. \& Kaya, O. N. (2011). Exploring preservice information technology teachers' perception of self-efficacy in web-technological pedagogical content knowledge. 6th International Advanced Technologies Symposium (IATS'11), Elazı̆̆, Türkiye.

Kazu, İ. Y. \& Erten, P. (2014). Teachers' technological content knowledge self-efficacies. Journal of Educational and Training Studies, 2(2), 126-144.

Koehler, M. J. \& Mischra, P. (2008). What is technological pedagogical content knowledge? Contemporary Issues in Technology and Teacher Education, 9(1), 60-70.

Kula, A. (2015). Öğretmen adaylarının teknolojik pedagojik alan bilgisi (TPAB) yeterliklerinin incelenmesi: Bartın Üniversitesi örneği. Akademik Sosyal Araştırmalar Dergisi, 3(12), 395-412.

Kurt, G., Mishra, P., \& Koçoğlu, Z. (2013). Technological pedagogical content knowledge development of Turkish pre-service teachers of English. Paper presented at the meeting of the Society for Information Technology and Teacher Education, New Orleans, LA.

Murat, A. \& Erten, H. (2016). Fen bilgisi öğretmen adaylarının teknopedagojik eğitim alanındaki öz yeterlik alg1 düzeyleri. The Journal of Academic Social Sciences Studies, 48, 477-485.

Öz, H. (2015). Assessing Pre-service English as a Foreign Language Teachers' Technological Pedagogical Content Knowledge. International Education Studies; 8(5), 119-130.

Russell, M., Bebell, D., O’Dwyer, L. \& O’Connor, K. (2003). Examining teacher technology use: Implications for pre-service and in service teacher preparation. Journal of Teacher Education, 54(4), 297-310.

Şimşek, Ö., Demir, S., Bağçeci, B. \& Kinay, İ. (2013). Öğretim elemanlarının teknopedagojik eğitim yeterliliklerinin çeşitli değişkenler açısından incelenmesi. Ege Eğitim Dergisi, 14(1), 1-23.

Tondeur, J. Roblin, N. P., van Braak, J. Fisser, P. \& Voogt, J. (2012): Technological pedagogical content knowledge in teacher education: in search of a new curriculum, Educational Studies, 1-5. DOI: $10.1080 / 03055698.2012 .713548$.

Tuncer, M. \& Bahadır, F. (2016). Öğretmen adaylarının teknopedagojik alan bilgisi yeterlikleri ve öğretmenlik mesleğine yönelik tutumları açısından incelenmesi. Turkish Studies, International Periodical for the Languages, Literature and History of Turkish or Turkic, 11(9), 839-858.

Ünal Bozcan, E. (2010). Eğitim öğretim faaliyetlerinde teknoloji kullanımı, Eğitim Teknolojileri Araştırmaları Dergisi, 1(4), 1-13. 


\section{İngilizce öğretmeni adaylarının teknopedagojik içerik bilgisi seviyeleri üzerine bir araştırma}

\section{Öz}

$\mathrm{Bu}$ çalışmanın amacı İngilizce öğretmeni adaylarının teknolojik pedagojik içerik bilgisi seviyelerini ve bazı değişkenlerin bu seviyeye etkisi olup olmadığını belirlemektir. TPACK modeli diğer teknoloji temelli modellerle karşılaştıııldığında teknolojik yeterliliklerin yanına içerik bilgisini de eklemesi açısından farklıdır. Katılımcılar Sakarya ve İstanbul'da iki devlet üniversitesinde okuyan 182 İngilizce Öğretmeni adayıdır. Veri Kabakçı Yurdakul, Odabaşı, Kılıçer, Çoklar, Birinci ve Kurt (2012) tarafından geliştirilen TPACK-Deep ölçeği ile toplanmıştır. Analizler SPSS aracılığıyla yapılmış ve okunan yıl, cinsiyet, internette harcanan günlük zaman ve sosyal medyada harcanan günlük zamanın değişkenlerinin etkisi de çalışılmıştır. Çalışma sonuçları katılımcıların genel manada TPACK modelinde ve üç alt boyutta yüksek bir yeterliliğe sahip olduğunu ancak sadece Etik alt boyutunda orta seviyede bir yeterliliğe sahip olduğunu göstermektedir. Değişkenlerde ise hiçbirisi TPACK modelinde genel manada anlamlı bir farklılığa sebep olmamakla birlikte cinsiyet ve internette harcanan günlük zamanın sadece Tasarım alt boyutunda anlamlı farklılığa sebep olduğu gözlemlenmiştir. Çalışmadaki analizler öğretmen adaylarının teknoloji, pedagoji ve içerik bilgisindeki yeterliliği hakkında fikir vermektedir. Bu çalışmanın bulgularının İngilizce öğretmeni yetiştirme alanına ve teknolojinin içerik ve pedagojik bilgiye başarılı bir şekilde entegre edilmesine katkıda bulunması beklenmektedir.

Anahtar sözcükler: Technopedagojik içerik bilgisi; TPACK, İngilizce Öğretmeni Adayları; teknoloji; içerik bilgisi

\section{AUTHOR BIODATA}

Cihat Atar is an assistant professor at Sakarya University in Faculty of Education.

Selami Aydın is a professor At Istanbul Medeniyet University Faculty of Education.

Hakkı Bağcı is an assistant professor at Sakarya University. 